\title{
A review on Terminalia arjuna (Roxb.) Wight \& Arn.: The wonder medicinal plant with prodigious potential in therapeutics
}

\author{
Sandip D. Desai ${ }^{\star}$, Sandeep R. Pai** and Neetin S. Desai*** \\ Life and Allied Sciences, Department of Bioscience, ITM University, Navi Mumbai-410201, Mumbai, Maharashtra, India \\ **Department of Botany, Rayat Shikshan Sanstha's, Dada Patil Mahavidyalaya, Karjat-414402, Ahmednagar, Maharashtra, India \\ ***Sunandan Divatia School of Science, SVKM's Narsee Monjee Institute of Management Studies, Deemed to be University, Bhakti Vedanta \\ Swami Marg, Vile-Parle, Mumbai-400056, Maharashtra, India
}

\section{Article Info}

\section{Article history}

Received 25 February 2021

Revised 18 April 2021

Accepted 19 April 2021

Published online 30 June 2021

\section{Keywords}

Terminalia arjuna

Cardioprotective

Hepatoprotective

Anti-inflammatory

Antioxidant.

\begin{abstract}
Terminalia arjuna (Roxb.) Wight \& Arn., a medicinal plant belonging to the family Combretaceae is known to display rich phytochemical profile. TA harbors several bioactive molecules such as glycosides, flavonoids, tannins, triterpenoids, phenolics and minerals. This review is an attempt to cover various clinical and experimental studies that reveals the clinical relevance of this plant. Most of the studies have indicated that TA possesses various medicinal properties like cardioprotective, hepatoprotective, antitumor, antibacterial, antioxidant, gastric, molluscicidal, anthelmintic, antidiabetic, antiviral and anti-inflammatory. This plant is also reported to enhance wound healing and bone mineralization process. This review presents no potential toxicity imposed by this plant extract but reflects the requirement of more extensive studies to be conducted in order to understand the long-term effect along with its molecular mechanism. This comprehensive review also provides information on various food products made using TA plant extract.
\end{abstract}

\section{Introduction}

From ancient times till today, medicinal plants have been a source of major components for traditional sources of medicine to cure human diseases owing to the concept of green medicine which serves as a healthier option when compared to the synthetic medicinal therapies. WHO also supports this fact that about $80 \%$ of the world population is dependent on traditional medicine and in India, $60 \%$ of the people in rural areas use herbal medicine (Heinrich, 2000). This plant based traditional system of medicine is a part of Indian culture and heritage which is dependent on Ayurveda, Siddha and Unani. This traditional medicine system encompasses practices and skills based on presumptions, knowledge, experience, belief of communities to cure various health problems (Ghosh, 2003). Use of herbal supplements in human consumption to promote health and nutritional status has seen an upsurge from $2.5 \%$ to $12 \%$ in the last few years owing to the increasing awareness about the importance of medicinal plants (Stickel and Schuppan, 2007). Use of herbal drugs made from bark, seeds, root, leaves, flowers and berries of medicinal plants seeks high demand from consumers as it offers plenty of advantages such as easy access, abundant availability, cost-effectiveness, highly efficient and possesses rare side effects. The medicinal use of plants is often attributed to the presence of secondary metabolite or bioactive compounds such as

Corresponding author: Mr. Sandip D. Desai

Life and Allied Sciences, Department of Bioscience, ITM University, Navi Mumbai-410201, Mumbai, Maharashtra, India

E-mail: desaisandip1984@gmail.com

Tel.: +91-9823216725

Copyright $(\odot) 2021$ Ukaaz Publications. All rights reserved.

Email: ukaaz@yahoo.com; Website: www.ukaazpublications.com glycosides, alkaloids, tannins, steroids, flavonoids, phenols, volatile oil that is naturally accumulated in them and imparts definite physiological actions on human body when consumed. The evaluation of new drugs that incorporates utilization of phytochemicals has altogether opened new doors for extensive research and further assists in smoother transition from traditional medicine to modern medicine in India (Amalraj and Gopi, 2016).

\section{Terminalia arjuna (Roxb.) Wight \& Arn.}

Terminalia arjuna (Roxb.) Wight \& Arn., is an ayurvedic plant which holds important medicinal value. It is commonly known as Arjuna, Dhavala, Kaubha, Nadisaraja Partha, Indradru and Veeravriksha belonging to the family Combretaceae. Almost 24 species of Terminalia have been reported in various part of India, of which few are T. arjuna, T. bellirica, T. catappa, T. bialata, T. mantaly, T. elliptica, T. porphyrocarpa, etc. It is a large evergreen deciduous tree that is found at several places in India and grows to a height of 60-80 feets. It commonly grows on banks of streams and rivers and is found to be distributed throughout the greater part of Indian sub-continent, Himalayan face of Uttar Pradesh, West Bengal, Deccan, Bihar, Madhya Pradesh, Orissa, Punjab and Konkan (Asif Ali et al., 2003; Kapoor et al., 2014; Sharma et al., 2000). It is also known by various vernacular names like Arjun (Hindi), Tella Maddi (Telugu), Marudhu (Malayalam and Tamil), Arjhan (Bengali), Sadado (Gujarati), Sadaru (Marathi), Neer matti (Kannada) and some traditional formulation is given in name of Arjunaghrita and Arjunarishta (Amalraj and Gopi, 2016). This tree displays spreading crowns, drooping branches and new leaves during the hot season (February to April). TA is grown through ripe seeds, pollarding, stumps, coppicing and air layering. Initial phase of its growth is 
noticed to be slow but later faster growth rate is attained and this tree grows 2-3 meters in three years (Asif Ali et al., 2003).

\section{Structure characteristics}

Leaves of TA grow to about $15-25 \mathrm{~cm}$ in length and $6-7.5 \mathrm{~cm}$ in width. They are simple, alternate thick-coriaceous, base obtusesubcordate. Margin of the leaves are crenate-serrate, apex is subacute or obtuse, pale brown beneath and pale green above. Petiole is 0.6$0.9 \mathrm{~cm}$ long and leaves exhibit oil glands at the abaxial surface of the leaf near petiole. The stem bark is smooth, simple, pinkish gray externally whereas the inner surface is soft, longitudinally striated and red in color. Barks have pieces that are curved, flat and rectangular in shape (Gupta et al., 2018). Flower of TA is white or yellowish and is found in groups with short auxiliary spikes or terminal panicle arrangement. Flowering phase of this plant occurs in summer and fruit appears in winter or spring season. Fruits of this plant are 11.5 inch in diameter with 5-7 longitudinal lobes. Fruits are glabrous with 5-7 wings, fibrous and woody. These fruits are drupe and are found to be notched near the top along with oblique upward curving striations (Ali, 2019).

\section{Phytochemical constituent}

TA harbors many phytochemicals in root bark, stem bark, leaves, fruits and seeds. Root exhibits presence of triterpenoids and glycosides whereas fruit contains triterpenoids and flavonoids. Seeds and leaves are known to contain flavonoid and glycosides. Amongst all the plant parts, bark of T. arjuna is considered most crucial constituent from medicinal point of view due to presence of flavonoids, tannins, glycosides, polyphenols, saponins, triterpenoids, sterols and minerals such as zinc, calcium, magnesium, copper, amino acids (Chaudhari and Mahajan, 2015; Chaudhari and Mengi, 2006).

TA bark contains a large amount of triterpenoids like arjunin, arjunic acid, arjunolic acid, arjungenin and terminic acid. Glycosides like triterpane, arjunetin, arjunoside I, arjunoside II, arjunaphthanoloside, terminoside $\mathrm{A}$, termiarjunoside 1 , termiarjunoside 2 and Sitosterol are also reported in stem bark. Arjunglucoside IV and V, arjunasides A-E were also found in ethanolic extract of the stem bark of T. arjuna (Deshpande et al., 2003; Khaliq and Fahim, 2017) (Table 1). TA bark is known to contain a very high level of flavonoids in comparison to other commonly used plants in Ayurveda. Types of flavonoids found in the bark of the plant are arjunone, luteolin, quercetin, flavones, gallic acid, ethyl gallate, baicalein, proanthocyanidins, catechin, gallocatechin, pelargonidin and kaempferol (Table 1). Flavonoids are popular phytochemicals owing to their antimutagenic and antibacterial properties. The aqueous extract from TA was revealed to harbor $70 \%$ polyphenols with molecular weight greater than $3.5 \mathrm{kDa}$ (Dwivedi, 2007; Khaliq and Fahim, 2017). The antibacterial property of this plant is mainly attributed to the presence of such bioactive compounds which serves as strong antioxidant and antiproliferative agents. Various constituents of tannins that are found in the bark of TA are pyrocatechol, castalagin, punicallin, punicalagin and terflavin (Khaliq and Fahim, 2017) (Table 1). Tannins have been speculated to possess hypotensive, astringent, antioxidant, wound- healing, and antimicrobial effects (Dwivedi and Agarwal, 1994).

Table 1: Bioactive compounds of $T$. arjuna bark extract

\begin{tabular}{|c|c|c|c|c|}
\hline Chemical type & Major chemical constituents & Molecular formula & Molecular weight & Reference \\
\hline \multirow{5}{*}{ Triterpenoids } & Arjunin & $\mathrm{C}_{41} \mathrm{H}_{26} \mathrm{O}_{26}$ & $934.6 \mathrm{~g} / \mathrm{mol}$ & Row et al., 1970 \\
\hline & Arjunic acid & $\mathrm{C}_{30} \mathrm{H}_{48} \mathrm{O}_{5}$ & $488.7 \mathrm{~g} / \mathrm{mol}$ & Row et al., 1970 \\
\hline & Arjungenin & $\mathrm{C}_{30} \mathrm{H}_{48} \mathrm{O}_{6}$ & $504.7 \mathrm{~g} / \mathrm{mol}$ & Honda et al., 1976 \\
\hline & Terminic acid & $\mathrm{C}_{30} \mathrm{H}_{48} \mathrm{O}_{4}$ & $472.7 \mathrm{~g} / \mathrm{mol}$ & Anjaneyulu and Prasad, 1983 \\
\hline & Arjunolic acid & $\mathrm{C}_{30} \mathrm{H}_{48} \mathrm{O}_{5}$ & $488.7 \mathrm{~g} / \mathrm{mol}$ & Singh et al., 2002 \\
\hline \multirow{3}{*}{ Glycosides } & Arjunetin & $\mathrm{C}_{36} \mathrm{H}_{58} \mathrm{O}_{10}$ & $650.8 \mathrm{~g} / \mathrm{mol}$ & Row et al.,1970 \\
\hline & Arjunolone & $\mathrm{C}_{16} \mathrm{H}_{12} \mathrm{O}_{5}$ & $284.2 \mathrm{~g} / \mathrm{mol}$ & Sharma et al., 1982 \\
\hline & Arjunglucoside I & $\mathrm{C}_{36} \mathrm{H}_{58} \mathrm{O}_{11}$ & $666.8 \mathrm{~g} / \mathrm{mol}$ & Wang et al., 2010 \\
\hline \multirow{10}{*}{$\begin{array}{l}\text { Flavonoids and } \\
\text { phenolics }\end{array}$} & Arjunone & $\mathrm{C}_{19} \mathrm{H}_{20} \mathrm{O}_{6}$ & $344.4 \mathrm{~g} / \mathrm{mol}$ & Sharma et al., 198 \\
\hline & Luteolin & $\mathrm{C}_{15} \mathrm{H}_{10} \mathrm{O}_{6}$ & $286.24 \mathrm{~g} / \mathrm{mol}$ & Pettit et al., 1996 \\
\hline & Baicalein & $\mathrm{C}_{15} \mathrm{H}_{10} \mathrm{O}_{5}$ & $270.24 \mathrm{~g} / \mathrm{mol}$ & Gaikwad and Jadhav, 2018 \\
\hline & Ethyl gallate & $\mathrm{C}_{9} \mathrm{H}_{10} \mathrm{O}_{5}$ & $198.17 \mathrm{~g} / \mathrm{mol}$ & Gaikwad and Jadhav, 2018 \\
\hline & Gallic acid & $\mathrm{C}_{7} \mathrm{H}_{6} \mathrm{O}_{5}$ & $170.12 \mathrm{~g} / \mathrm{mol}$ & Gaikwad and Jadhav, 2018 \\
\hline & Kaempferol & $\mathrm{C}_{15} \mathrm{H}_{10} \mathrm{O}_{6}$ & $286.24 \mathrm{~g} / \mathrm{mol}$ & Gaikwad and Jadhav, 2018 \\
\hline & Proanthocyanidin & $\mathrm{C}_{31} \mathrm{H}_{28} \mathrm{O}_{12}$ & $592.5 \mathrm{~g} / \mathrm{mol}$ & Gaikwad and Jadhav, 2018 \\
\hline & Pelargonidin & $\mathrm{C}_{15} \mathrm{H}_{11} \mathrm{O}_{5}^{+}$ & $271.24 \mathrm{~g} / \mathrm{mol}$ & Gaikwad and Jadhav, 2018 \\
\hline & Quercetin & $\mathrm{C}_{15} \mathrm{H}_{10} \mathrm{O}_{7}$ & $302.23 \mathrm{~g} / \mathrm{mol}$ & Gaikwad and Jadhav, 2018 \\
\hline & $\begin{array}{l}\text { (+) catechin, } \\
(+) \text { gallocatechin }\end{array}$ & $\begin{array}{l}\mathrm{C}_{15} \mathrm{H}_{14} \mathrm{O}_{6} \\
\mathrm{C}_{15} \mathrm{H}_{14} \mathrm{O}_{7}\end{array}$ & $\begin{array}{l}290.27 \mathrm{~g} / \mathrm{mol} \\
306.27 \mathrm{~g} / \mathrm{mol}\end{array}$ & Saha et al., 2012 \\
\hline \multirow[t]{5}{*}{ Tannins } & Pyrocatechols & $\mathrm{C}_{6} \mathrm{H}_{6} \mathrm{O}_{2}$ & $110.11 \mathrm{~g} / \mathrm{mol}$ & Takahashi et al., 1997 \\
\hline & Punicalin & $\mathrm{C}_{34} \mathrm{H}_{22} \mathrm{O}_{22}$ & $782.5 \mathrm{~g} / \mathrm{mol}$ & Lin et al., 2000 \\
\hline & Castalagin & $\mathrm{C}_{41} \mathrm{H}_{26} \mathrm{O}_{26}$ & $934.6 \mathrm{~g} / \mathrm{mol}$ & Kuo et al., 2005 \\
\hline & Punicalagin & $\mathrm{C}_{48} \mathrm{H}_{28} \mathrm{O}_{30}$ & $1084.7 \mathrm{~g} / \mathrm{mol}$ & Kuo et al., 2005 \\
\hline & Terflavin $\mathrm{C}$ & $\mathrm{C}_{41} \mathrm{H}_{26} \mathrm{O}_{26}$ & $934.6 \mathrm{~g} / \mathrm{mol}$ & Kuo et al., 2005 \\
\hline
\end{tabular}


Table 2: Pharmacological studies on $T$. arjuna plant extract

\begin{tabular}{|c|c|c|c|c|}
\hline Role of TA & Extract & Model & Research findings & References \\
\hline $\begin{array}{l}\text { Cardioprotection } \\
\text { and antioxidant }\end{array}$ & $\begin{array}{l}\text { Methanolic } \\
\text { extract of bark }\end{array}$ & $\begin{array}{l}\text { Rats (in vitro model of } \\
\text { myocardial ischemic- } \\
\text { reperfusion injury) }\end{array}$ & $\begin{array}{l}\text { TA induced myocardial heat } \\
\text { shock protein } 72 \text { and augmented } \\
\text { endogenous antioxidants, without } \\
\text { causing any cellular injury. }\end{array}$ & Karunakaran, 2015 \\
\hline Cardioprotection & $\begin{array}{l}\text { Aqueous extract } \\
\text { of the bark }\end{array}$ & $\begin{array}{l}\text { Wistar male rats } \\
\text { (isoproterenol-induced } \\
\text { cardiac hypertrophy) }\end{array}$ & $\begin{array}{l}\text { TA partially or completely restored } \\
\text { the gene regulatory network } \\
\text { by ISO treatment in rat heart. }\end{array}$ & Kumar et al., 2019 \\
\hline $\begin{array}{l}\text { Cardioprotection } \\
\text { and antioxidant }\end{array}$ & $\begin{array}{l}\text { Aqueous extract } \\
\text { of the bark }\end{array}$ & Swiss albino mice & $\begin{array}{l}\text { TA protected the liver and kidney } \\
\text { tissues against } \mathrm{CCl}_{4} \text { induced } \\
\text { oxidative stress probably by } \\
\text { increasing antioxidative defense } \\
\text { activities. }\end{array}$ & Manna et al., 2006 \\
\hline $\begin{array}{l}\text { Cardioprotection } \\
\text { and antioxidant }\end{array}$ & $\begin{array}{l}\text { Ethanol and } \\
\text { aqueous extract } \\
\text { of bark }\end{array}$ & $\begin{array}{l}\text { Adult Wistar rats } \\
\text { (isoproterenol induced } \\
\text { myocardial infarction) }\end{array}$ & $\begin{array}{l}\text { TA offered biochemical and histo- } \\
\text { pathological protection as that of } \\
\text { standard drug (Verapamil) }\end{array}$ & $\begin{array}{l}\text { Sivakumar and } \\
\text { Shanmugam, } 2014\end{array}$ \\
\hline $\begin{array}{l}\text { Cardioprotection } \\
\text { and antioxidant }\end{array}$ & $\begin{array}{l}50 \% \text { aqueous } \\
\text { ethanol extract }\end{array}$ & $\begin{array}{l}\text { Wistar albino rats } \\
\text { (isoproterenol-induced } \\
\text { chronic heart failure) }\end{array}$ & $\begin{array}{l}\text { TA offered prophylactic and } \\
\text { therapeutic benefits by maintaining } \\
\text { endogenous antioxidant enzymeac- } \\
\text { tivities, inhibiting lipid peroxidation } \\
\text { and cytokine levels. }\end{array}$ & Parveen et al., 2011 \\
\hline $\begin{array}{l}\text { Cardioprotection } \\
\text { and antioxidant }\end{array}$ & $\begin{array}{l}\text { Ethanol extract } \\
\text { of the bark }\end{array}$ & $\begin{array}{l}\text { Male Swiss albino mice } \\
\text { (sodium fluoride-induced } \\
\text { oxidative stress) }\end{array}$ & $\begin{array}{l}\text { TA balanced the prooxidant- } \\
\text { antioxidant status of the heart } \\
\text { and enhanced the cardiac intracellular } \\
\text { antioxidant activity. }\end{array}$ & Sinha et al., 2008 \\
\hline $\begin{array}{l}\text { Cardioprotection } \\
\text { and antioxidant }\end{array}$ & $\begin{array}{l}\text { Alcoholic and } \\
\text { aqueous }\end{array}$ & $\begin{array}{l}\text { Wistar rats, Human } \\
\text { monocytic cells and } \\
\text { Human aortic } \\
\text { endothelial cells }\end{array}$ & $\begin{array}{l}\text { TA inhibited the lipid peroxidation } \\
\text { and HMG-CoA reductase but had no } \\
\text { effect on LpL. The extracts } \\
\text { attenuated } \mathrm{H}_{2} \mathrm{O}_{2} \text { mediated ROS } \\
\text { generation in THP-1 cells by } \\
\text { promoting antioxidant enzymes, } \\
\text { and by sustaining cellular reducing } \\
\text { power. Extracts decreased the levels } \\
\text { of typical inflammatory marker } \\
\text { proteins, viz. LPS induced TNF- } \alpha \text {, } \\
\text { VCAM-1 and E-selectin. }\end{array}$ & Kokkiripati et al., 2013 \\
\hline Cardioprotection & $\begin{array}{l}\text { Hydroalcoholic } \\
\text { extract of bark }\end{array}$ & Experimental rats & $\begin{array}{l}\text { TA significantly reversed the STZ/ISP } \\
\text { induced increase in CPK-MB, hs-CRP } \\
\text { levels and marked protection against } \\
\text { cardiac damage. }\end{array}$ & Suman et al., 2018 \\
\hline Cardioprotection & $\begin{array}{l}\text { Ethanolic extract } \\
\text { of bark }\end{array}$ & $\begin{array}{l}\text { Chronic coronary artery } \\
\text { disease }(C A D) \text { patients }\end{array}$ & $\begin{array}{l}\text { Arjuna is safe and effective in patients } \\
\text { with chronic coronary artery disease } \\
\text { till } 4.5 \text { years. Mild symtoms like } \\
\text { gastritis and constipation were } \\
\text { reported. }\end{array}$ & Dwivedi et al., 2019 \\
\hline Cardioprotection & $\begin{array}{l}90 \% \text { alcoholic } \\
\text { extract }\end{array}$ & $\begin{array}{l}\text { In vitro isolated perfused } \\
\text { rabbit's heart }\end{array}$ & $\begin{array}{l}\text { Cholinergic and adrenergic receptors } \\
\text { are not involved in mechanism of } \\
\text { TA action. }\end{array}$ & Jassal et al., 2013 \\
\hline Cardioprotection & $70 \%$ ethanol & $\begin{array}{l}\text { Male Swiss albino mice } \\
\text { (caffeine induced } \\
\text { coronary artery disease) }\end{array}$ & $\begin{array}{l}\text { Amelioration of body weight, heart } \\
\text { weight, biochemical parameter } \\
\text { and antioxidant enzymes. }\end{array}$ & Palanivelu, 2015 \\
\hline $\begin{array}{l}\text { Cardioprotection } \\
\text { and antioxidant }\end{array}$ & $\begin{array}{l}\text { Oral suspension } \\
(30 \mathrm{mg})\end{array}$ & $\begin{array}{l}\text { Rats subjected to } \\
\text { myocardial ischemia } \\
\text { induced by isoproterenol } \\
\text { and treated with abana } \\
\end{array}$ & $\begin{array}{l}\text { The reversal of cardiac injury enzyme } \\
\text { and improved heart mitochondrial } \\
\text { uptake. }\end{array}$ & Tandon et al., 1996 \\
\hline $\begin{array}{l}\text { Hypotensive } \\
\text { actions }\end{array}$ & $\begin{array}{l}\text { Aqueous and } \\
\text { alcoholic bark } \\
\text { extract }\end{array}$ & $\operatorname{Dog}($ in vivo) & $\begin{array}{l}\text { Dose dependent decrease in blood } \\
\text { pressure. }\end{array}$ & Singh et al., 1982 \\
\hline Cardioprotection & $\begin{array}{l}\text { Ethanolic extract } \\
\text { of bark }\end{array}$ & $\begin{array}{l}\text { Rabbit fed with high } \\
\text { fat diet }\end{array}$ & Reduced hyperlipidemia. & Ram et al., 1997 \\
\hline
\end{tabular}




\begin{tabular}{|c|c|c|c|c|}
\hline Antitumor & $\begin{array}{l}\text { Methanolic extract } \\
\text { of bark }\end{array}$ & MCF-7 cell line & $\begin{array}{l}\text { Inhibitory and anti-proliferative } \\
\text { action on breast cancer cell line. }\end{array}$ & Shalini et al., 2015 \\
\hline Antitumor & $\begin{array}{l}\text { Aqueous bark } \\
\text { extract }\end{array}$ & $\begin{array}{l}\text { Human lymphocyte } \\
\text { culture and bone marrow } \\
\text { cells of albino mice }\end{array}$ & $\begin{array}{l}\text { Reduced metaphase aberration, sister } \\
\text { chromatid exchanges and frequencies } \\
\text { in aberrant cells when compared to } \\
\text { mutagen treated positive control. }\end{array}$ & Ahmad et al., 2014 \\
\hline Antitumor & $\begin{array}{l}\text { Isolated arjunic } \\
\text { acid from bark }\end{array}$ & $\begin{array}{l}\text { Human oral, ovarian, } \\
\text { and liver cancer cell } \\
\text { lines }\end{array}$ & $\begin{array}{l}\text { Inhibitory and anti-proliferative } \\
\text { action on cell lines. }\end{array}$ & Saxena et al., 2007 \\
\hline Antitumor & Bark extract & $\begin{array}{l}\text { Cultured human } \\
\text { peripheral blood } \\
\text { lymphocytes }\end{array}$ & $\begin{array}{l}\text { Protects DNA against ADR-induced } \\
\text { damage. }\end{array}$ & Reddy et al., 2008 \\
\hline Antimicrobial & $\begin{array}{l}\text { Methanol, ethanol, } \\
\text { acetone and } \\
\text { aqueous extracts } \\
\text { from theleaves } \\
\text { and bark }\end{array}$ & $\begin{array}{l}\text { Staphylococcus aureus } \\
\text { Acinetobacter sp., } \\
\text { Proteusmirabilis, } \\
\text { Escherichia coli } \\
\text { and Pseudomonas } \\
\text { aeruginosa }\end{array}$ & $\begin{array}{l}\text { Acetone leaf extract was found to be } \\
\text { best against } S \text {. aureus. Organic } \\
\text { extract showed almost equal inhibition } \\
\text { of all Gram-negative bacteria except } \\
P \text {. aeruginosa. Aqueous extract of TA } \\
\text { bark exhibited good activity against } \\
\text { S. aureus. }\end{array}$ & Aneja et al., 2012 \\
\hline Antimicrobial & $\begin{array}{l}\text { Ethanolic extract } \\
\text { and its different } \\
\text { solvent fractions } \\
\text { (chloroform, ethyl } \\
\text { acetate, n-butanol } \\
\text { and aqueous } \\
\text { fraction) of bark } \\
\text { and leaves }\end{array}$ & $\begin{array}{l}\text { Bacillus subtilis, } \\
\text { Staphylococcus aureus, } \\
\text { Eschericia coli, } \\
\text { Klebsiella pneumoniae, } \\
\text { Pseudomonas } \\
\text { aeruginosa } \\
\text { and Salmonella typhi }\end{array}$ & $\begin{array}{l}\text { The n-butanol fraction of bark } \\
\text { showed more antioxidant potential } \\
\text { as compared to other solvents. }\end{array}$ & Kumar et al., 2018 \\
\hline Antimicrobial & Aqueous & $\begin{array}{l}\text { Actinobacillus } \\
\text { actinomycetemcomitans, } \\
\text { Porphyromonas } \\
\text { gingivalis, Prevotella } \\
\text { intermedia, Tanerella } \\
\text { forsythus }\end{array}$ & $\begin{array}{l}\text { Significant antimicrobial efficacy } \\
\text { on single and mixed cultures. }\end{array}$ & Karmakar et al., 2020 \\
\hline Antimicrobial & $\begin{array}{l}\text { Methanol and } \\
\text { aqueous extract } \\
\text { of bark }\end{array}$ & $\begin{array}{l}\text { Multidrug resistant } \\
\text { Salmonella typhi }\end{array}$ & Strong antibacterial activity. & Rani and Khullar, 2004 \\
\hline Antimicrobial & $\begin{array}{l}\text { Dichloromethane } \\
\text { and methanol } \\
\text { extract }\end{array}$ & $\begin{array}{l}\text { Staphylococusaureus, } \\
\text { Pseudomonas } \\
\text { aeruginosa, } \\
\text { Microspormcanis, } \\
\text { Aspergillusflavus, } \\
\text { Fusariumsolani } \\
\end{array}$ & Inhibitory action. & Javed et al., 2016 \\
\hline $\begin{array}{l}\text { Hepatoprotection } \\
\text { and antioxidant }\end{array}$ & $\begin{array}{l}\text { Aqueous extract } \\
\text { of bark }\end{array}$ & $\begin{array}{l}\text { Wistar albino rats } \\
\text { (Paracetamol/ } \mathrm{CCl}_{4} \\
\text { induced liver damage) }\end{array}$ & $\begin{array}{l}\text { Amelioration of liver marker } \\
\text { enzymes and histopatological } \\
\text { changes. }\end{array}$ & Vishwakarma et al., 2013 \\
\hline $\begin{array}{l}\text { Hepatoprotection } \\
\text { and antioxidant }\end{array}$ & $\begin{array}{l}\text { Aqueous extract } \\
\text { of bark }\end{array}$ & $\begin{array}{l}\text { Mice model }\left(\mathrm{CCl}_{4}\right. \\
\text { challenged) }\end{array}$ & $\begin{array}{l}\text { Modulated levels of antioxidant } \\
\text { enzymes and mitigated the } \mathrm{CCl}_{4} \\
\text { induced changes as comparable } \\
\text { to vitamin C. }\end{array}$ & Manna et al., 2006 \\
\hline $\begin{array}{l}\text { Hepatoprotection } \\
\text { and antioxidant }\end{array}$ & $\begin{array}{l}70 \% \text { ethanol } \\
\text { of bark }\end{array}$ & $\begin{array}{l}\text { Experimental mice } \\
\left(\mathrm{CCl}_{4} \text { challenged }\right)\end{array}$ & $\begin{array}{l}\text { Oral treatment of the active } \\
\text { constituents of TA at a dose of } \\
50 \mathrm{mg} / \mathrm{kg} \text { body weight for } \\
7 \text { days prior to } \mathrm{CCl}_{4} \text { administration } \\
\text { significantly restored the activities } \\
\text { of all antioxidant enzymes. }\end{array}$ & Manna et al., 2007 \\
\hline $\begin{array}{l}\text { Hepatoprotection } \\
\text { and antioxidant }\end{array}$ & $\begin{array}{l}\text { Aqueous bark } \\
\text { powder extract }\end{array}$ & $\begin{array}{l}\text { Rats (alcohol } \\
\text { induced hepato } \\
\text { and nephrotoxicity) }\end{array}$ & $\begin{array}{l}\text { Reduced lipid peroxidation and } \\
\text { restored levels of enzymatic and } \\
\text { non-enzymatic antioxidants. }\end{array}$ & Hebbani et al., 2015 \\
\hline $\begin{array}{l}\text { Hepatoprotection } \\
\text { and antioxidant }\end{array}$ & $\begin{array}{l}\text { Ethyl acetate } \\
\text { extract of the } \\
\text { heartwood }\end{array}$ & HepG2 cells & $\begin{array}{l}\text { Significantly ameliorated levels of } \\
\text { antioxidant enzymes, normalised } \\
\text { the PPAR } \gamma \text { expression, reduced } \\
\text { steatosis and MNC infiltration. }\end{array}$ & Toppo et al., 2018 \\
\hline Hepatoprotection & Aqueous extract & Wistar albino male rats & $\begin{array}{l}\text { The biochemical, antioxidant, } \\
\text { histopathological, CYP2E1 enzyme, } \\
\text { PI3K, AKT protein expression } \\
\text { analysis were shown increased }\end{array}$ & Kannappan et al., 2020 \\
\hline
\end{tabular}




\begin{tabular}{|c|c|c|c|c|}
\hline & & & $\begin{array}{l}\text { antioxidant level, increased } \\
\text { PI3K/AKT level, decreased liver } \\
\text { function marker level and decreased } \\
\text { CYP2E1 level in animals treated } \\
\text { with TA. }\end{array}$ & \\
\hline Anti-inflammatory & $\begin{array}{l}\text { Arjuna Ksheera } \\
\text { paka and } \\
\text { hydroalcoholic } \\
\text { extract }\end{array}$ & $\begin{array}{l}\text { Carrageenan-induced } \\
\text { hind paw biphasic } \\
\text { edema in C57BL/6 } \\
\text { mice }\end{array}$ & $\begin{array}{l}\text { Both the extracts, showed significant } \\
\text { anti-inflammatory activity in } \\
\text { reducing paw edema in mice. }\end{array}$ & Dube et al., 2017 \\
\hline Anti-inflammatory & $\begin{array}{l}\text { Aqueous extract } \\
\text { of bark }\end{array}$ & Sprague dawely rats & $\begin{array}{l}400 \mathrm{mg} / \mathrm{kg} \text { dose of TA aqueous extract } \\
\text { of bark decreased the size of paw } \\
\text { edema in carrageenan induced } \\
\text { edema in rats. }\end{array}$ & Rana et al., 2016 \\
\hline Wound healing & $\begin{array}{l}\text { Bark powder } \\
\text { mixed with } \\
\text { coconut oil }\end{array}$ & $\begin{array}{l}65 \text { years old male } \\
\text { patient of non-healing } \\
\text { multiple ulcers }\end{array}$ & $\begin{array}{l}\text { TA healed large, non healing, tender, } \\
\text { recurrent ulcers with secondary } \\
\text { infection. }\end{array}$ & Dudhamal, 2016 \\
\hline Wound healing & $\begin{array}{l}\text { Herbal } \\
\text { formulations } \\
\text { (Himax ointment } \\
\text { and lotion) }\end{array}$ & Rats (wound model) & $\begin{array}{l}\text { Improved wound contracting ability, } \\
\text { epithelization period, tensile strength } \\
\text { and regeneration of tissues at the } \\
\text { wound area. The results were found } \\
\text { comparable to standard drug } \\
\text { nitrofurazone. }\end{array}$ & Mukherjee et al., 2003 \\
\hline $\begin{array}{l}\text { Wound healing } \\
\text { and antimicrobial }\end{array}$ & $\begin{array}{l}\text { Hydroalcohol } \\
\text { extract of the bark }\end{array}$ & $\begin{array}{l}\text { Rats (wound model), } \\
\text { Pseudomonas } \\
\text { aeruginosa, } \\
\text { Escherichia coli, } \\
\text { Staphylococcus } \\
\text { aureus, } \\
\text { Streptococcus } \\
\text { pyogenes }\end{array}$ & $\begin{array}{l}\text { Increase in the tensile strength of the } \\
\text { incision wounds, increased percent } \\
\text { epithelialization of excision wounds } \\
\text { and potential antimicrobial activity } \\
\text { against microorganisms. }\end{array}$ & $\begin{array}{l}\text { Chaudhari and Mengi, } \\
2006\end{array}$ \\
\hline $\begin{array}{l}\text { Gastroproductive } \\
\text { effect }\end{array}$ & $\begin{array}{l}\text { Methanolic } \\
\text { extract }\end{array}$ & $\begin{array}{l}\text { Diclofenac sodium } \\
\text { induced gastric ulcer } \\
\text { in male albinorats } \\
\text { of Wistar }\end{array}$ & $\begin{array}{l}\text { TA extracts ameliorate various } \\
\text { impairments associated with DNA } \\
\text { damage and free radical formation. } \\
\text { Significant reduction in lesion index } \\
\text { was observed in ulcer induced animals. }\end{array}$ & Devi et al., 2007 \\
\hline Molluscicidal & $\begin{array}{l}\text { Column purified } \\
\text { fractions, arjunolic } \\
\text { acid and } \\
\text { procynadine }\end{array}$ & $\begin{array}{l}\text { Snail Lymnaea } \\
\text { acuminata }\end{array}$ & $\begin{array}{l}\text { Inhibited acetylcholinesterase (AChE) } \\
\text { acid phosphatase (ACP) and alkaline } \\
\text { phosphatase (ALP) activities in the } \\
\text { cerebral ganglion of } L \text {. acuminata. }\end{array}$ & Soni et al., 2017 \\
\hline Molluscicidal & Ethanolic extract & $\begin{array}{l}\text { Snail (Indoplanorbis } \\
\text { exustus. I. exustus) } \\
\end{array}$ & $\begin{array}{l}\text { Time and concentration dependent } \\
\text { molluscicidal activity. }\end{array}$ & Soni and Singh, 2015 \\
\hline Anthelmintic & $\begin{array}{l}\text { Stem bark extract } \\
\text { using chloroform, } \\
\text { ethanol and water }\end{array}$ & $\begin{array}{l}\text { Live earthworms } \\
\text { Pheretima posthuma }\end{array}$ & $\begin{array}{l}\text { Significant antioxidant and } \\
\text { anthelmintic activity. }\end{array}$ & Bodke et al., 2013 \\
\hline Anthelmintic & $\begin{array}{l}\text { Methanolic extract } \\
\text { of bark }\end{array}$ & $\begin{array}{l}\text { Haemonchus } \\
\text { contortus ova and larva }\end{array}$ & $\begin{array}{l}\text { Dose-dependent anthelmintic } \\
\text { activity both in the in vitro } \\
\text { and in vivo studies. }\end{array}$ & Bachaya et al., 2009 \\
\hline Antidiabetic & Ethanolic extract & $\begin{array}{l}\text { Alloxan induced } \\
\text { diabetic rats }\end{array}$ & $\begin{array}{l}\text { Reduction inlipid peroxidation, } \\
\text { amelioration of antioxidant } \\
\text { enzyme activity and oxidative stress. }\end{array}$ & $\begin{array}{l}\text { Raghavan and Kumari, } \\
2006\end{array}$ \\
\hline Antiviral & $\begin{array}{l}\text { Casuarinin, } \\
\text { isolated from TA }\end{array}$ & $\begin{array}{l}\text { Herpes simplex type } 2 \\
(\mathrm{HSV}-2) \text { in vitro }\end{array}$ & $\begin{array}{l}\text { Casuarinin possessed } \\
\text { anti-herpes virus activity in inhibiting } \\
\text { viral attachment and penetration, } \\
\text { and also disturbing the late event } \\
\text { of infection. }\end{array}$ & Cheng et al., 2002 \\
\hline Antiviral & Ethanolic extract & $\begin{array}{l}\text { Human hepatoma } \\
\text { cell line (HepG2) }\end{array}$ & $\begin{array}{l}\text { Inhibited the proliferation of HepG } 2 \\
\text { cells in a concentration-dependent } \\
\text { manner along with DNA } \\
\text { fragmentation, accumulation of p53, } \\
\text { cleavage of procaspase- } 3 \text { protein } \\
\text { and depletion of GSH. }\end{array}$ & $\begin{array}{l}\text { (Sivalokanathan } \\
\text { et al., } 2006\end{array}$ \\
\hline $\begin{array}{l}\text { Improving } \\
\text { endothelial } \\
\text { dysfunction }\end{array}$ & $\begin{array}{l}\text { TA capsule } \\
(500 \mathrm{mg})\end{array}$ & $\begin{array}{l}\text { Healthy male } \\
\text { smokers }\end{array}$ & $\begin{array}{l}\text { Improvement in flow-mediated } \\
\text { dilation from baseline values } \\
\text { and significant regression of } \\
\text { endothelial abnormality } \\
\text { in } 2 \text { weeks of treatment. }\end{array}$ & Bharani et al., 2004 \\
\hline
\end{tabular}


Bark also contains $34 \%$ ash entirely constituting calcium carbonate. Aqueous extract of TA has previously been reported to show $16 \%$ tannins content and $23 \%$ calcium salts (Chitlange et al., 2009). The major chemical constituent found in the roots on TA are sitosterol, triterpenoids (arjunic acid, arjunolic acid, oleanolic acid, terminic acid) and glycosides (arjunoside I-IV). Leaves and fruits have also been revealed to be rich sources of glycosides and luteolin like flavonoids (Khaliq and Fahim, 2017).

\section{Pharmacological significance of $T$. arjuna}

Since ancient times TA is known to treat many dreadful diseases. It has been an important constituent of our Ayurveda as well as Allopathy medicinal system due to its wide range of therapeutic properties. It holds immense potential to cure various disease and medical conditions (Table 2).

\subsection{Cardioprotective activity}

The arjuna plant has been called by name "Guardian of the heart" owing to its property of treating heart diseases since time immemorial. Researchers have demonstrated cardioprotective role of TA extract in isoproterenol induced myocardial infarction, isoproterenol induced cardiac hypertrophy, myocardial ischemic reperfusion injury, hypertension and ischaemic heart disease, etc., (Karunakaran, 2015; Kumar et al., 2019; Manna et al., 2006; Sivakumar and Shanmugam, 2014). The reversal of cardiac injury enzyme and improved heart mitochondrial uptake is also reported in rats, subjected to myocardial ischemia induced by isoproterenol when TA was supplemented in $30 \mathrm{mg}$ oral dose (Tandon et al., 1996). Ethanolic extract of TA bark has been reported to exhibit oxidative stress ameliorating activity in murine heart and incase of ISO-induced chronic heart failure by inhibiting process of lipid peroxidation as well as maintenance of endogenous antioxidant enzyme activities (Parveen et al., 2011; Sinha et al., 2008). Another report indicated the cholesterol level maintenance property of TA owing to its vitamin E like antioxidant properties that strengthens the heart muscles and ensures its functioning adequately. It was also found to be effective in treatment of coronary artery disease (CAD), angina, hypercholesterolemia, heart failure, asthma, diuretic and coronary related risk factors (Sivakumar and Shanmugam, 2014). At molecular levels, TA extract is revealed to be a potent inhibitor of human 3-hydroxy-3-methylglutaryl coenzyme A (HMG-CoA), CYP3A4, CYP2C9 and CYP2D6 and displays non-competitive binding ability to these enzymes in human liver microsomes (Kokkiripati et al., 2013; Varghese et al., 2015). Various aspects of the effect of TA on cardiovascular function, its molecular mechanism along with histological studies are well established (Khaliq and Fahim, 2017). Suman et al., (2018) have suggested a modulatory role of TA extract in diabetic experimental models co-existing with cardiovascular problems (Suman et al., 2018). A recent pharmacovigilant study on 35 chronic CAD patients supplemented with $500 \mathrm{mg}$ of bark extract thrice daily, claimed the long term safety of TA and proposed it as an adjunct drug in CAD (Dwivedi et al., 2019). Studies have been conducted to understand the pharmacological effects of $90 \%$ alcoholic extracts of TA on heart and coronary blood flow. This study revealed the cardiac depressant activity of the arjuna plant that is routed without involvement of cholinergic and adrenergic receptors (Jassal et al., 2013). Researchers have also unfolded the antihyperlipidemic activity of the bark extract in caffeine induced mice thereby suggesting its relevance in caffeine induced coronary heart diseases (Palanivelu, 2015). Cardiachemodynamics study on aqueous as well as alcoholic bark extract on isolated frog atria showed reduction in the heart rate whereas increased coronary flow in the isolated rabbit heart (Gaikwad and Jadhav, 2018). Hypotensive action of aqueous and ethanolic extract was also found to cause dose dependent decrease in blood pressure in an in vivo study on dogs (Singh et al., 1982) Alcoholic extracts of TA powder are also reported to reduce hyperlipidemia and cause no alteration in prothrombin time in rabbit model system (Gaikwad and Jadhav, 2018; Ram et al., 1997). Patients with dilated cardiomyopathy with or without heart failure and reduced left ventricular ejection fraction owing to either idiopathic or ischemic, when received combined standard therapy and herbal medication showed significant improvement in systolic and diastolic functions as well as functional capacity in comparison to those receiving only standard therapy or only herbal medications (Bhawani et al., 2013). Aqueous extract of TA induced cardiotonic action in adult ventricular myocytes isolated from hearts of male sprague-dawley rats is reported by enhancing sarcoplasmic reticular function thereby, minimizing the occurrence of arrhythmias, suggesting the promising and safe cardiotonic effect to the heart health and the treatment for chronic heart diseases (Oberoi et al., 2011). Overall the prophylactic and therapeutic repercussions of TA extract are well established and understood.

\subsection{Antitumor potential}

TA has been previously reported to display anti-proliferative effect in human breast cancer cell lines owing to its rich bioactive constituent profile (Shalini et al., 2015). The anticancer properties of this plant extract is investigated in detail using in vivo and in vitro model systems which has revealed its cytotoxic activity (Ahmad et al., 2014). It has been reported to be active in carcinoma, lymphoma, human oral, ovarian and liver cancer cell lines unfolding its superior potential to be have as antineoplastic agent (Ramesh et al., 2012; Saxena et al., 2007). Bark extract of TA is also recognized to protect DNA against ADR induced damage by minimizing the oxidative stress levels along with inhibition of anaerobic metabolism, thereby flaunting its excellent application as herbal medicine against environmental carcinogenicity (Reddy et al., 2008). Anti-carcinogenic and antimutagenic potential of TA was also evaluated using human lymphocytes and bone marrow of albino mice as assay systems. The researchers stated that TA causes significant reduction in metaphasic aberrations and sister chromatid exchanges induced by aflatoxin B1 both in the in vitro and in vivo system. On the other hand, the replication index was enhanced suggesting the dose and time dependent ameliorating potential of Terminalia extract (Ahmad et al., 2014).

\subsection{Antibacterial activity}

Extract of TA in various solvent systems have been found to be harboring antibacterial activity against various gram-positive and gram-negative organisms such as Pseudomonas aeruginosa, Eschericia coli, Bacillus subtilis, salmonella typhi and staphylococcus aureus (Kumar et al., 2018). A potent antibacterial activity of methanolic extract of this plant has been reported to be antimicrobial against multidrug resistant, Salmonella typhi, Pseudomonas aeruginosa and Staphylococcus aureus along with moderate antifungal effect against Microsporum canis (Javed et al., 2016; Rani and Khullar, 2004). The arjuna leaves and bark extract has 
been investigated to harbor excellent antigrowth properties that retards the growth of organisms causing ear infections and, thus are used to formulate herbal ear drops. These herbal ear drops have been found to be more effective when compared to the standard ear drops (Aneja et al., 2012). Antimicrobial efficacy of this plant is also reported against periodontopathogens like Actinobacillus actinomycetemcomitans, Porphyromonas gingivalis, Prevotella intermedia and Tannerella forsythia, thereby suggesting its potential in treating periodontal diseases (Karmakar et al., 2020). TA extracts have been found to be medicinal in nature by inhibiting respiratory pathogens also that cause infections in the lower and upper respiratory tract region (Kumar et al., 2014).

\subsection{Hepatoprotective effect}

TA has shown to bear excellent hepatoshielding effect against carbon tetrachloride $\left(\mathrm{CCl}_{4}\right)$ or paracetamol induced damage in wistar rats. This biochemical effect was revealed to be due to significant reduction in activity of various enzymes like serum alkaline phosphatase, serum glutamic pyruvic transaminase, serum glutamic oxaloacetic transaminase and serum bilirubin which was found to be in the same levels when rats were treated with standard hepatoprotective agent (Vishwakarma et al., 2013). Manna and his team indicated the modulatory role of arjunolic acid against arsenic induced cytotoxicity in murine hepatocytes in 2007 and protective consequence of bark extract against $\mathrm{CCl}_{4}$ induced liver damage in 2006 (Manna et al., 2006, 2007). TA bark aqueous extract have been also reported to be active in reducing the alcohol induced nephrotoxicity in experimental rats by mitigating the levels of lipid peroxides and restoration of enzymatic along with nonenzymatic antioxidants in liver (Hebbani et al., 2015). The hepatoprotective and antioxidative effect of TA bark extract has been evidently suggested in cadmium mediated hepatotoxicity (Haidry and Malik, 2014). Furthermore, arjuna extract has extended beneficial effect in curing nonalcoholic fatty acid liver disease by decreasing the lipid levels in palmitateoleate incubated HePG2 cell and by minimizing the activity of lactate dehydrogenase (LDH), alanine aminotransferase (ALT), aspartate transaminase (AST) and gamma glutaryl transferase (GGT) in HFD models (Toppo et al., 2018). Kannappan and his team have also suggested the antioxidant effect of this plant extract against acetaminophen induced hepatotoxicity via the regulation of cytochrome P450 2E1, phosphatidylinositol-3- kinase/ protein kinase B (Kannappan et al., 2020).

\subsection{Antioxidant activity}

The cardioprotective, antitumor activity, antibacterial and hepatoprotective effect of TA can be attributed to its antioxidant nature which has been reported by several studies mentioned before. Bioactive constituent profiling of bark extract has revealed it to be a superior source of antioxidants like flavonoids, tannins, proanthocyanidins, etc. Arujunic acid and aglycone found in the fruits of this plant has been suggested to be a very strong antioxidant or free radical scavenger and more effective than ascorbic acid (Sun et al., 2008). Extract of TA harboring casuarinin is reported to defend Madin Darby canine Kidney (MDCK) cells against hydrogen peroxide induced stress by alleviating the DNA damage and replenishing the levels of intracellular reduced glutathione (Chen $e t$ al., 2004). TA is also recognized as a hypocholesterolemic and hypolipidemic agent that can mitigate oxidative stress induced by a high fat high cholesterol diet (Sharma and Agarwal, 2012). In vitro investigation comparing the antioxidant properties of TA bark and core wood revealed that the core wood of the tree possesses more antioxidant molecules in comparison to bark. This study also supports methanol as the best solvent to extract antioxidant compounds from this plant (Ramesh et al., 2013).

\subsection{Anti-inflammatory activity}

The effect of TA extract was revealed to inhibit nitric oxide production in lipopolysaccharide induced rat peritoneal macrophages by expressing a strong antioxidant activity (Ali et al., 2003). The extract of TAalong with Datura stramonium and Withania somnifera have been reported to exhibit anti-inflammatory activity. The antiinflammatory and analgesic action of this formulation can be attributed to the inhibition of cyclooxygenase (COX) enzyme, thereby interfering with the production of prostaglandins (Mukesh et al., 2010). Dube and his colleagues investigated the antiinflammatory efficacy TA ayurvedic formulation prepared in cow milk, i.e., Arjuna Ksheera paka and unfolded the better efficacy of Ksheera paka when compared to hydroalcoholic extract. The researchers proposed that presence of milk solids behaves as an adjuvant to arjuna bioactive, constituents thereby causing enhanced bioavailability and efficacy of the drug at lower concentration (Dube et al., 2017). Saxena and his team conducted a detailed investigation of TA bark and revealed that its bioactive constituent expressed immunostimulatory response at lower dose whereas, at higher concentration, they were found to exhibit immunosuppressive activity (Saxena et al., 2008). Another team of researchers proposed and proved anti-inflammatory activity on carrageenan induced paw edema in the rat model system. They stated that the aqueous extract of the plant bark can significantly reduce the carrageenan induced edema in experimental animals (Rana et al., 2016).

\subsection{Wound healing activity}

The TA bark powder has been reported to treat chronic wounds along with the coconut oil (Dudhamal, 2016). A study reports wound healing potential of arjuna extract in form of a formulation of Himax ointment and lotion which was comparable to standard nitrofurazone drugs (Mukherjee et al., 2003). TA hydroalcohol extract has also been documented for its beneficial effect on rat dermal wounds when applied topically owing to its superior tannin content (Chaudhari and Mengi, 2006).

\subsection{Gastric activity}

Various studies have reported that arjuna has greater potential to curb the damage caused to gastric mucosa by different agents. Devi and her team investigated and confirmed the antiulcer repercussions of methanolic extract of TA against Helicobacter pylori lipopolysaccharide mediated gastric damage in experimental rats (Devi et al., 2008). Not only this, these extract can enhance the adherent mucus in the gastric walls along with the protein bound carbohydrate molecules of gastric juices in diclofenac treated rats models (Devi et al., 2007).

\subsection{Molluscicidal and anthelmintic properties}

The molluscicides activity of TA is established on Lymnaea acuminata and Indoplanorbis exustus (Soni and Singh, 2015; Soni and Singh 2019a). The thin layer chromatography analysis showed the presence of bioactive components from TA extract to cause molluscicidal activity against $L$. acuminata. Further, the consequence 
of arjunolic acid on key enzymes AchE, ACP and ALP activity was investigated in the nervous tissue of $L$. acuminata snail and displayed its dose dependent inhibition of these enzymes (Soni et al., 2017). Upon a detailed study on the kinetics of these enzymes, it was putforth that inhibition of AchE was noncompetitive, whereas inhibition of ALP and ACP was competitive-non-competitive and non-competitive respectively. Also, inhibition of ALP by TA extract was more evident and visible as compared to the other two enzymes. A different team of researcher determined the toxicity and safety aspects of a molluscicidal drug made from TA on Colisa fasciatus (an aquatic model) and added that lethal concentration 90 reported in L. acuminata and I. exustus did not impose any toxic effect on nervous tissue of fish in $24 \mathrm{~h}$ (Soni and Singh, 2019b).

Anthelmintic effect of TA was studied on Pheretima posthuma and was found to retard the spontaneous movement of these helminthes and cause death of trematodes (Bodke et al., 2013). Also, methanolic extract of TA was revealed to be efficient against larvae and hatched eggs of Haemonchus contortus at the dose of 467 and $645 \mu \mathrm{g} / \mathrm{ml}$, respectively suggesting the medicinal nature of TA (Bachaya et al., 2009).

\subsection{Antidiabetic activity}

A previously cited work has shown the modulatory role of TA extract in diabetes existing along with cardiovascular complications (Suman et al., 2018). The ethanolic extract of TA was found to ameliorate the alloxan induced diabetes in experimental rat models by stabilizing the enzymatic, non-enzymatic activity and minimizing the levels of oxidative stress in liver and kidney tissues (Raghavan and Kumari, 2006).

\subsection{Antiviral and apoptosis related studies}

Casuannin, a bioactive component of TA has proven to be antiviral in nature. Studies have been conducted on Herpes simplex type II virus in vitro condition and showed that the active molecule potently inhibited viral attachment and penetration of the virus (Cheng et al., 2002).

Apoptosis is a form of programmed cell death (PCD) that brings about characteristic change in the cell and leads to cell death. The changes encompass cell shrinkage, blebbing, nuclear DNA fragmentation, chromatin condensation, and mRNA decay. The role of TA bark extract in inducing apoptosis of a human liver cancer cell line (HepG2) was investigated and showed that the apoptotic effect was due to induction of DNA damage and over expression of apoptotic proteins along with possible exhaustion of reduced glutathione levels (Sivalokanathan et al., 2006). TA also is proposed to promote foam cell and macrophage apoptosis by enhancing UPRmediated JHN/p38MAOK-CHOP pathway activation in a DUSP1dependent manner, thereby suggesting a possible connection between ox-LDL-induced ER stress and TA mediated MAPK signaling (Bhansali et al., 2019). A double blind, placebo controlled, crossover designed study on 18 symptomatic smokers revealed the modulatory effect of TA on endothelial dysfunction by revealing the improved brachial artery flow mediated dilation (Bharani et al., 2004).

\subsection{Other physiological effects}

A study validated that arjuna bark extract exhibits synergistic effect with phytochemicals on different pathways leading to better bioactivity and bone mineralisation. The biocomposite prepared using bark extract displayed enhanced compression strength and stability. The functional groups of arjuna extract help in biomineralization in vitro and showed positive influence on cell differentiation and cell viability in MG-63 cells. Such biocomposite can be used as excellent bone filler or as a coating agent in metallic implants to impart bioactivity (Krithiga et al., 2014).

\section{Toxicity or side effects}

A study was conducted in order to understand an acute and subchronic toxicity of TA leaf in Swiss albino mice. No mortality was observed during the course of the entire study period and no noticeable alterations were revealed in hematological, biochemical and histological parameters treated group when compared to vehicle control group post 28 days emphasizing its safe nature (Moulisha et al., 2011). The effect of arjuna extract on tissue lead (Pb) concentration in rats was experimented by Senapati et al. (2005). Their study reported no synergistic toxicity of arjuna and extract but revealed the prophylactic efficacy of extract. Their report suggests that concomitant use of arjuna bark extract at three different doses was found to reduce $\mathrm{Pb}$ concentration considerably in these vital organs indicating the potential therapeutic activity of arjuna against lead toxicity (Senapati et al., 2005).

TA is usually used in the dose between 1 to $2 \mathrm{~g}$ per day and is found to be the optimum and effective dose in the patients with cardiovascular diseases. Few reports have suggested the mild side effects of these doses such as headache, mild gastritis and constipation. There are no reports in context to hematological, hepatic, metabolic and renal toxicity even after 24 months and more than two years of its administration (Gupta et al., 2018).

Overall, this review presents that TA possesses various medicinal properties like cardioprotective, hepatoprotective, antitumor, antibacterial, antioxidant, gastric, molluscicidal, anthelmintic, antidiabetic, antiviral and anti-inflammatory with no reported side effects (Figure 1).

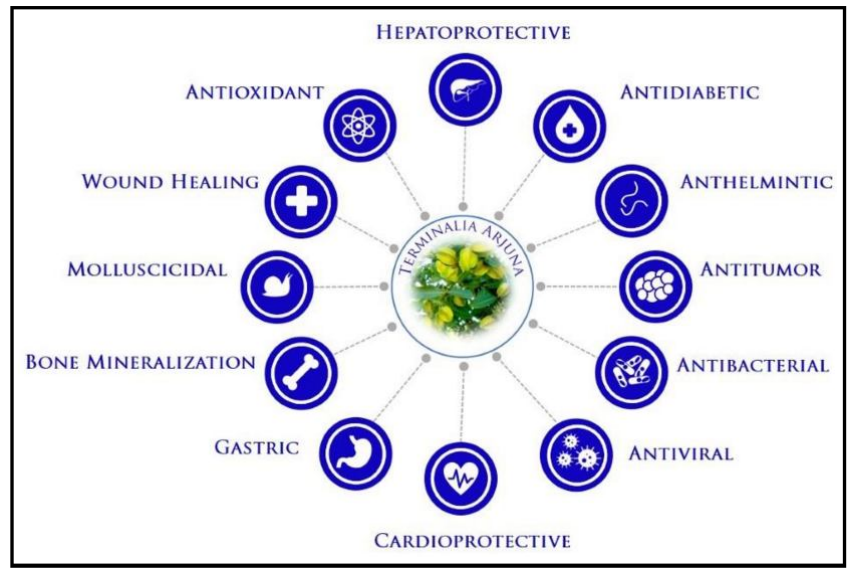

Figure 1: Beneficial medicinal properties of T. arjuna. 


\section{Studies on incorporation of T. arjuna in food products}

About $39 \%$ of the total milk produced in India is converted into butter and ghee. The clarified milk fat, i.e., ghee has a unique property of absorbing the medicinal characteristics of the fortified herbs without diminishing or losing its own qualities. The herbal ghee presently is being marketed and sold as medicine, i.e., medicinal ghee. These types of products harbor a typical flavor, a bitter or pungent taste and a dark color. Such therapeutic products or preparations are not suitable for regular consumption by consumers.

Arjuna ghee has been developed for extending beneficial health effects against cardiovascular disease. The ghee has exhibited more stability to oxidative deterioration as compared to conventional ghee owing to the rich phenolic bioactive compounds present in TA plants. The consumer acceptability of this product on the basis of sensory analysis has been reported to be very good. In daily diet, arjuna ghee can be replaced with regular ghee unlike medicated ghee preparations that is not used for regular purpose. The rich repository of the antioxidants present in the arjuna herbs lead to their usage into fat rich dairy products for retarding auto-oxidation there by prolonging the shelf-life (Upadhyay et al., 2001).

Churna is a mixture of powdered herbs and minerals which are used in Ayurvedic medicine. Arjuna churna is sold under different names by popular brands like Patanjali, Baidyanath and Dabur. This churna is used to prevent heart ailments most popularly. Systematic comparison of high-performance liquid chromatogram of standardized and marketed Arjuna churna formulation revealed eight common peaks in an acetonitrile-water gradient program that can serve as a fingerprint to this formulations. This has been the basis of preparation of churna (Chitlange et al., 2009).

Bishnoi and Ahlawat (2015). have used TA extract for development of buffalo meat rolls by supplementing the extracts at 2, 4 and $6 \%$ level each so as to optimize the amount of extract incorporation. The effect of co-supplementation on the texture profile of the developed products was also studied. $2 \%$ extract of arjuna tree bark was suitable for incorporation and selected for further studies on the basis of sensory scores. The physical properties of the developed products were also studied and compared to control samples. Their report overall indicated that male buffalo calf meat rolls can be developed by incorporating $2 \%$ arjuna tree bark extracts with good sensory and textural properties thereby, unfolding new application of TA extract (Bishnoi and Ahlawat, 2015).

Recently, utilization of TA at 2, 4 and $6 \%$ was evaluated for development of herbal multigrain biscuits as cardiotonic. The results revealed that $2 \%$ TA containing biscuits had lesser ash content, lower spread ratio, nominal diameter, less moisture and more thickness in comparison to control biscuits. Incorporation of TA at $2 \%$ did not affect the overall acceptability of the biscuits and possesses potential to enhance the nutritional status for people with cardiac diseases, without minimizing the sensory acceptability of the composite biscuits. Co-supplementation of higher percentage of TA resulted in darker color along with undesirable taste, thereby affecting the overall acceptability of the bakery product (Alifiya $e t$ al., 2018).

Furthermore, a herbal green tea was developed using Withania somnifera stems, TA bark, Cinnamon bark and Tinospora cordifolia stems. The phytochemical, nutritional, antioxidant and antibacterial activity analysis showed that the formulation mixture of these herbs reflected them to be an excellent source of nutraceuticals and flavoring agents. A perfect physical and psychological health rejuvenator was made from these herbs that possesses potential to extend multiple health benefits to the diet conscious consumers. This report also presents this herb formulation based infusion as a new alternative to the traditional flavored teas (Namdev and Gupta, 2015).

Sawale and team, 2016 evaluated the hypolipidemic potential along with the antioxidative properties of encapsulated herb (TA in 1.8\%) added with vanilla chocolate dairy drink in high cholesterol fed Wistar rats for 60 days. A significant decrease in serum lipids such as total cholesterol, triglycerides, very-low-density lipoprotein cholesterol, low-density lipoprotein cholesterol, and atherogenic index was observed with encapsulated herb. The results obtained from their study revealed that the bioactive components (flavonoids, phytosterols, saponins, tannins, etc.) which are present in encapsulated TA gets effectively released in the intestine to display their effects and can also withstand the adverse processing conditions. This encapsulated herb study also supports and presents TA as a potential medicinal plant candidate bearing hypolipidemic and antioxidant activities that can treat cardiovascular disease (Sawale et al., 2016).

Sharma et al. (2012). developed arjuna omelette and arjuna upma composition with good sensory properties of arjuna omelette in comparison to upma. Their results showed that coconut chutney with sambar soppu scored highest for all sensory attributes followed by bisebilebath and little millet upma with drumstick leaves and the least scores were obtained for barnyard millet upma with drumstick leaves (Sharma et al., 2012).

\section{A global perspective of research on T. arjuna}

A total of 683 publications on TA have been reported upon on a global search and retrieval from Scopus database ranging from 19972019 publication year. The cumulative global research registers $169.19 \%$ growth and $8 \%$ as annual increase in the publications. The plant global citation impact averaged to 16.92 citations per paper (CPP) in twenty-two years, which decreased from 36.02 to 9.82 CPP from 1997-2007 to 2008-2018. India accounts for the highest and largest publication share of $82.43 \%$ and other 9 countries from $1.02 \%$ to $5.27 \%$ during 1997-2018. Pharmacology, toxicology and pharmaceutics, among seven broad subjects, contributed the largest publications share of $50.51 \%$, followed by medicine $(30.31 \%)$, biochemistry, genetics and molecular biology (26.52\%), agricultural and biological sciences $(21.52 \%)$ and other 3 sub-fields contribution varying from $4.54 \%$ to $10.83 \%$ during 1997-18 (Ahmed et al., 2020). This data certainly points out the potential of TA and extensive studies conducted on it with the objective of exploring its potential in curing various diseases and expounding its therapeutic role in development of novel formulation.

\section{Conclusion}

Experimental and clinical studies compiled in this review indicate that TA possesses immense ethanopharmacological significance owing to its various medicinal properties. The properties of this plant are attributed to the presence of various phytoconstituents such as glycosides, flavonoids, tannins, triterpenoids and phenolics. 
TA is been reported to possess cardioprotective, hepatoprotective, antitumor, antibacterial, antioxidant, gastric, molluscicidal, anthelmintic, antidiabetic, antiviral and anti-inflammatory properties. Such medicinal phytochemical rich plants behave as potent resource for future drug discoveries. Maximum efforts and extensive investigation should be undertaken to characterize all phytochemicals in such medicinal plants at molecular level. Such investigation can establish new standard drugs with lesser toxicity when accompanied with in-silico analysis and clinical trials so as to benefit global population.

\section{Conflict of interest}

The authors declare that there is no conflicts of interest, relevant to this article.

\section{Reference}

Ahmad, M.S.; Ahmad, S.; Gautam, B.; Arshad, M. and Afzal, M. (2014). Terminalia arjuna a herbal remedy against environmental carcinogenicity: An in vitro and in vivo study. Egyptian Journal of Medical Human Genetics, 15:61-67.

Ahmad, M.U.; Mullah, K.B.; Norin, T. and Ulla, J.K. (1983). Terminoic acid, a new trihydroxytriterpene carboxylic acid fromxm.m.,b n.bmv,b,j bark of Terminalia arjuna. Indian J. Chem., 22:738-740.

Ahmed, K.K.M.; Gupta, B.M.; Singh, N. and Kumar, A. (2020). Global research on Terminalia arjuna: A quantitative and qualitative assessment of publications during 2004-18. Pharmacognosy Reviews, 14:1-10.

Alam, M.S.; Kaur, G.; Ali, A.; Hamid, H.; Ali, M. and Athar, M. (2008). Two new bioactive oleanane triterpene glycoside from Terminalia arjuna. Nat. Prod. Res., 22:1279-1288.

Ali Asif, Kaur, G.; Hamid, H.; Abdullah, T.; Ali, M.; Niwa, M. and Alam, M.S. (2003) Terminoside A, a new triterpene glycoside from the bark of Terminalia arjuna inhibits nitric oxide production in murine macrophages. Journal of Asian Natural Products Research, 5:137-142.

Ali, A.; Kaur, G.; Hayat, K.; Ali, M. and Ather, M. (2003). A novel naphthanol glycoside from Terminalia arjuna with antioxidant and nitric oxide inhibitory activities, Pharmazie, 58:932-934.

Alifiya, Bishnoi, J.P.; Shree, A. and Gupta, S. (2018). Utilization of Terminalia arjuna for development of herbal multigrain biscuits. Int. J. Fauna Biol. Stud., 5:228-232.

Amalraj, A. and Gopi, S. (2016). Medicinal properties of Terminalia arjuna (Roxb.) Wight and Arn.: A review. J. Tradit. Complement Med., 7:65-78.

Aneja, K.R., Sharma, C. and Joshi, R. (2012). Antimicrobial activity of Terminalia arjuna Wight \& Arn.: An ethnomedicinal plant against pathogens causing ear infection. Brazilian Journal of Otorhinolaryngology, 78:68-74.

Anjaneyulu, A.S. and Prasad, A.V. (1983). Structure of terminic acid, a dihydroxytriterpene carboxylic acid from Terminalia arjuna. Phytochemistry, 22:993-998.

Bachaya, H.; Iqbal, Z; Khan, M.; Jabbar, A.; Gilani, A. and Islam-Ud-Din. (2009) In vitro and in vivo anthelmintic activity of Terminalia arjuna bark. International Journal of Agriculture and Biology, 11:273-278.

Bhansali, S.; Khatri, S. and Dhawan, V. (2019). Terminalia arjuna bark extract impedes foam cell formation and promotes apoptosis in ox-LDLstimulated macrophages by enhancing UPR-CHOP pathway. Lipids in Health and Disease, 18:195.
Bharani, A.; Ahirwar, L.K. and Jain, N. (2004). Terminalia arjuna reverses impaired endothelial function in chronic smokers. Indian Heart J., 56:123-128.

Bhawani, G.; Kumar,A.; Murthy, K.S.N.; Kumari, N. and Ganapati Swami, C. (2013). A retrospective study of effect of Terminalia arjuna and evidence based standard therapy on echocardiographic parameters in patients of dilated cardiomyopathy. Journal of Pharmacy Research, 6:493498 .

Bishnoi, S. and Ahlawat, S.S. (2015). Development of buffalo meat rolls incorporated with Aloe vera gel and arjun tree bark extract. Haryana Veterinarian, 54:174-177.

Bodke, Y.; Sindhe, A.; Gupta R. and Manjunatha, H. (2013). Antioxidant and anthelmintic activity of Terminalia arjuna roxb. stem bark extracts. Asian Journal of Pharmaceutical and Clinical Research, 6(4):33-37.

Chaudhari, G.M. and Mahajan, R.T. (2015). Comprehensive study on pharmacognostic, physico and phytochemical evaluation of Terminalia arjuna Roxb. stem bark. Journal of Pharmacognosy and Phytochemistry, 4(3):186-193.

Chaudhari, M. and Mengi, S. (2006). Evaluation of phytoconstituents of Terminalia arjuna for wound healing activity in rats. Phytother Res, 20:799-805.

Chen, C.H.; Liu, T.Z.; Kuo, T.C.; Lu, F.J.; Chen, Y.C.; Chang-Chien, Y.W. and Lin, C.C. (2004). Casuarinin protects cultured MDCK cells from hydrogen peroxide-induced oxidative stress and DNA oxidative damage. Planta Med, 70:1022-1026

Cheng, H.Y.; Lin, C.C. and Lin, T.C. (2002). Antiherpes simplex virus type 2 activity of casuarinin from the bark of Terminalia arjuna Linn. Antiviral Res, 55:447-455.

Chitlange, S.S.; Kulkarni, P.S.; Patil, D.; Patwardhan, B. and Nanda, R.K. (2009). High-performance liquid chromatographic fingerprint for quality control of Terminalia arjuna containing Ayurvedic churna formulation. J. AOAC. Int., 92:1016-1020.

Deshpande, S.S.; Shah, G.B. and Parmar, N.S. (2003). Antiulcer activity of Tephrosia purpurea in rats. Indian Journal of Pharmacology, 35(3): 168-172.

Devi, R.S.; Kist, M.; Vani, G. and Devi, C.S.S. (2008). Effect of methanolic extract of Terminalia arjuna against Helicobacter pylori 26695 lipopolysaccharide-induced gastric ulcer in rats. Journal of Pharmacy and Pharmacology, 60:505-514.

Devi, R.S.; Narayan, S.; Vani, G. and Shyamala Devi, C.S. (2007). Gastroprotective effect of Terminalia arjuna bark on diclofenac sodium induced gastric ulcer. Chem. Biol. Interact., 167:71-83.

Dube, N.; Nimgulkar, C. and Bharatraj, D.K. (2017). Validation of therapeutic anti-inflammatory potential of Arjuna Ksheera Paka - A traditional Ayurvedic formulation of Terminalia arjuna. J. Tradit. Complement. Med., 7:414-420.

Dudhamal, T. (2016). Wound healing activity of Arjuna bark powder in Dushta vrana (Non healing venous ulcers). A case report. Journal of Ayurvedic and Herbal Medicine, 2:102-103.

Dwivedi, S. (2007). Terminalia arjuna Wight \& Arn.: A useful drug for cardiovascular disorders. J. Ethnopharmacol, 114:114-129.

Dwivedi, S. and Agarwal, M.P. (1994). Antianginal and cardioprotective effects of Terminalia arjuna, an indigenous drug, in coronary artery disease. J. Assoc. Physicians. India, 42:287-289.

Dwivedi, S.; Chopra, D. and Bhandari, B. (2019). Role of Terminalia arjuna Wight and Arn. in the treatment of chronic coronary artery disease from pharmacovigilance point of view. Ayu., 40:104-108.

Dwivedi, S. and Udupa, N. (1989). Terminalia arjuna: Pharmacognosy, phytochemistry, pharmacology and clinical use a review. Fitoterapia, 60:413-420. 
Gaikwad, D. and Jadhav, N. (2018). A review on biogenic properties of stem bark of Terminalia arjuna: An update. Asian Journal of Pharmaceutical and Clinical Research, 11(8):35-39.

Ghosh, A. (2003). Herbal folk remedies of Bankura and Medinipur districts, West Bengal. IJTK, 2(4):393-396.

Gupta, S.; Bishnoi, J.P.; Kumar, N. and Kumar, H. (2018). Terminalia arjuna (Roxb.) Wight \&Arn.: Competent source of bioactive components in functional food and drugs. Pharma. Innovation, 7:223-231.

Haidry, M.T. and Malik, A. (2014). Hepatoprotective and antioxidative effects of Terminalia arjuna against cadmium provoked toxicity in albino rats (Ratus norvigicus). Biochemistry and Pharmacology, 3:1-4.

Hebbani, A.; Reddy, V.D. and Varadacharyulu, N. (2015). Protective effect of aqueous bark extract of Terminalia arjuna against alcohol-induced hepato and nephrotoxicity in rats. International Journal of Phytomedicine, 7:142-153.

Heinrich, M. (2000). Ethnobotany and its role in drug development. Phytother. Res., 14:479-488.

Honda, T.; Murae, T.; Tsuyuki, T.; Takahashi, T. and Sawai, M. (1976). Arjungenin, arjunglucoside I and arjunglucoside II, a new triterpene and new triterpene-glucosides from Terminalia arjuna. Bull. Chem. Soc. Jpn., 49:3213-3218.

Jassal, B.; Kumar, B.; Bajaj, V. and Walia, R. (2013). Cardiodepressant activity of $90 \%$ alcoholic extract of Terminalia arjuna and its probable mechanism of action. International Journal of Medical and Dental Sciences, 2:144-152.

Javed, T.; Riaz, S.; Uzair, M.; Mustafa, G.; Mohyuddin,A. and Bashir, A. C. (2016) Biological activity of Terminalia arjuna on human pathogenic microorganisms. Pakistan Journal of Pharmaceutical Research, 2(1):23.

Kannappan, S.P.; Raghunath, G.; Sivanesan, S.; Vijayaraghavan, R. and Swaminathan, M. (2020). Antioxidant effect of Terminalia arjuna extract against acetaminophen-induced hepatotoxicity via the regulation of cytochrome $\mathrm{P} 450$ 2E1, phosphatidylinositol-3-kinase/ protein kinase B. Pharmacognosy Magazine, 16:13.

Kapoor, D.; Vijayvergiya, R. and Dhawan, V. (2014). Terminalia arjuna in coronary artery disease: ethnopharmacology, pre-clinical, clinical and safety evaluation. J. Ethnopharmacol, 155:1029-1045.

Karmakar, S.; Srinath, R.; Prakash, S. and Mahesh, J. (2017). Antimicrobial efficacy of Terminalia arjuna on potent periodontopathogens: An in vitro study. WJPLS, 3(4):240-243.

Karunakaran, G. (2015). Cardioprotective role of methanolic extract of bark of Terminalia arjuna against in vitro model of myocardial ischemic-reperfusion injury. Ancient Science of Life, 35:79.

Khaliq, F. and Fahim, M. (2017). Role of Terminalia arjuna in improving cardiovascular functions: A review Indian J. Physiol. Pharmacol., 62(1):8-19.

Kokkiripati, P.K.; Kamsala, R.V.; Bashyam, L.; Manthapuram, N.; Bitla, P.; Peddada, V.; Raghavendra, A.S. and Tetali, S.D. (2013). Stem-bark of Terminalia arjuna attenuates human monocytic (THP-1) and aortic endothelial cell activation. J. Ethnopharmacol, 146:456-464.

Krithiga, G.; Hemalatha, T.; Deepachitra, R.; Ghosh, K. and Sastry, T.P. (2014). Study on osteopotential activity of Terminalia arjuna bark extract incorporated bone substitute. Bull. Mater. Sci., 37:1331-1338.

Kumar, G.; Saleem, N.; Kumar, S.; Maulik, S.K.; Ahmad, S.; Sharma, M. and Goswami, S.K. (2019). Transcriptomic validation of the protective effects of aqueous bark extract of Terminalia arjuna (Roxb.) on isoproterenol-induced cardiac hypertrophy in Rats. Front. Pharmacol., 10:1-9.

Kumar, S.; Kumar, K. and Navneet, (2014). Evaluation of antimicrobial and phytochemical properties of Terminalia arjuna linn. Extracts against respiratory tract pathogens. International Journal of Current Research, 6:8003-8005.
Kumar, V.; Sharma, N.; Sourirajan, A.; Khosla, P.K. and Dev, K. (2018). Comparative evaluation of antimicrobial and antioxidant potential of ethanolic extract and its fractions of bark and leaves of Terminalia arjuna from north-western Himalayas, India. Journal of Traditional and Complementary Medicine, 8:100-106.

Kuo, P.L.; Hsu, Y.L.; Lin, T.C.; Lin, L.T.; Chang, J.K. and Lin, C.C. (2005).Casuarinin from the bark of Terminalia arjuna induces apoptosis and cell cycle arrest in human breast adenocarcinoma MCF-7cells. Planta Med., 71:237-243.

Lin, T.C.; Chien, S.C.; Chen, H.F. and Hsu, F.L. (2000). Tannins and related compounds from Combretaceae plants. Chin. Pharm. J., 52:1-26.

Manna, P.; Sinha, M. and Sil, P.C. (2007). Phytomedicinal activity of Terminalia arjuna against carbon tetrachloride induced cardiac oxidative stress. Pathophysiology, 14:71-78.

Manna, P.; Sinha, M. and Sil, P.C. (2006). Aqueous extract of Terminalia arjuna prevents carbon tetrachloride induced hepatic and renal disorders. BMC Complement Altern. Med., 6:33.

Moulisha, B.; Karan, T.; Bhattacharya, S.; Kumar, R.B.S. and Halda, P. (2011). Acute and sub-chronic toxicity study of Terminalia arjuna leaf in Swiss albino mice. Pharmacology Online, 1:1-4.

Mukesh, C. S. and Sharma, S. (2010). Phytochemical, preliminary pharmacognostical and antimicrobial evaluation of combined crude aqueous extract. Int. J. Microbiol. Res., 1(3):166-170.

Mukherjee, P.K.; Mukherjee, K.; Rajesh Kumar, M.; Pal, M. and Saha, B.P. (2003). Evaluation of wound healing activity of some herbal formulations. Phytother Res., 17:265-268.

Namdev, P. and Gupta, R.K. (2015). Herbal green tea formulation using Withania somnifera stems, Terminalia arjuna bark, Cinnamon bark and Tinospora cordifolia stems and nutritional and phytochemical analysis. Journal of Pharmcognosy and Phytochemistry, 4(2):282291.

Oberoi, L.; Akiyama, T.; Lee, K.H. and Liu, S.J. (2011). The aqueous extract, not organic extracts, of Terminalia arjuna bark exerts cardiotonic effect on adult ventricular myocytes. Phytomedicine, 18:259-265.

Palanivelu, S. (2015). Antihyperlipidemic activity of the bark extract of Terminalia arjuna in caffeine induced mice. Indian Journal of Applied Research, 5:311.

Parveen, A.; Babbar, R.; Agarwal, S.; Kotwani, A. and Fahim, M. (2011). Mechanistic clues in the cardioprotective effect of Terminalia arjuna bark extract in isoproterenol-induced chronic heart failure in rats. Cardiovasc Toxicol, 11:48-57.

Pettit, G.R.; Hoard, M.S.; Doubek, D.L.; Schmidt, J.M.; Pettit, R.K. and Tackett, L.P. (1996). Antineoplastic agents 338 . The cancer cell growth inhibitory. Constituents of Terminalia arjuna (Combretaceae). J. Ethnopharmacol, 53:57-63.

Raghavan, B. and Kumari, S.K. (2006). Effect of Terminalia arjuna stem bark on antioxidant status in liver and kidney of alloxan diabetic rats. Indian J. Physiol. Pharmacol., 50:133-142.

Ram, A.; Lauria, P.; Gupta, R.; Kumar, P. and Sharma, V.N. (1997). Hypocholesterolaemic effects of Terminalia arjuna tree bark. J. Ethnopharmacol, 55:165-169.

Ramesh A. S.; Christopher, G. and Thankamani, V. (2013). Comparative study on antioxidant property of Terminalia arjuna bark and corewood. Research Journal of Pharmacy and Technology, 6:996-1000.

Ramesh,A.S.; Christopher, J.G.; Radhika, R.; Setty, C.R. and Thankamani, V. (2012). Isolation, characterisation and cytotoxicity study of arjunolic acid from Terminalia arjuna. Natural Product Research, 26:1549-1552.

Rana, M.S.; Walia, R.; Dixit, A. and Raina, K. (2016). To compare and evaluate the anti-inflammatory efficacy of Terminalia arjuna (aqueous extract of bark) with diclofenac sodium on rats. International Journal of Basic \& Clinical Pharmacology, 5:692-695. 
Rani, P. and Khullar, N. (2004). Antimicrobial evaluation of some medicinal plants for their antienteric potential against multidrug resistant Salmonella typhi. Phytother. Res., 18:670-673.

Reddy, T.K.; Seshadri, P.; Reddy, K.K.R.; Jagetia, G.C. and Reddy, C.D. (2008). Effect of Terminalia arjuna extract on adriamycin-induced DNA damage. Phytother. Res., 22:1188-1194.

Row, L.R.; Murty, D.S.; Subbarao, G.S.; Sastry, C.S. and Rao, K.V. (1970). Chemical examination of Terminalia arjuna: Part-III- Isolation and structure determination of arjunetin from Terminalia arjuna, species. Indian J. Chem., 8:772-775.

Saha, A.; Pawar, V.M. and Jayaraman, S. (2012). Characterization of polyphenols in Terminalia arjuna bark extract. Indian J. Pharm. Sci., 74:339347

Sawale, P.D.; Pothuraju, R.; Abdul Hussain, S.; Kumar,A.; Kapila, S. and Patil, G.R. (2016). Hypolipidaemic and antioxidative potential of encapsulated herb (Terminalia arjuna) added vanilla chocolate milk in high cholesterol fed rats. J. Sci. Food Agric., 96:1380-1385.

Saxena, M.; Faridi, U.; Mishra, R.; Gupta, M.M.; Darokar, M.P.; Srivastava, S.K.; Singh, D.; Luqman, S. and Khanuja, S.P. (2007). Cytotoxic agents from Terminalia arjuna. Planta Med., 73:1486-1490.

Saxena, M.; Yadav, S.; Bawankule, D.U.; Srivastava, S.K.; Pal,A.; Mishra, R.; Gupta, M.M.; Darokar, M.P. and Priyanka Khanuja, S.P.S. (2008). An Immunomodulator from Terminalia arjuna and biological evaluation of its eerivatives. Natural Product Communications, 3:1934578X0 800300613 .

Senapati, S.K.; Dey, S. and Dwivedi, S.K. (2005). Effect of Arjuna (Terminalia arjuna) Extract on tissue lead levels in rats. Pharmaceutical biology, 43:696-700.

Shalini, S.; Kumar, R.R. and Birendra, S. (2015). Antiproliferative effect of phytosome complex of methanolic extact of Terminalia arjuna bark on human breast cancer cell lines (MCF-7). International Journal of Drug Development and Research, 7(1):173-182.

Sharma, P.C.; Yelne, M.B.; Dennis, T.J.; Joshi, A. and Billore, K.V. (2000). Database on medicinal plants used in Ayurveda.

Sharma, P.N.; Shoeb, A.; Kapil, R.S. and Popli, S.P. (1982). Arjunolone: A new flavones from stem bark of Terminalia arjuna. Indian J. Chem., 21B:263-264.

Sharma, S.; Agarwal, D and Agarwal, N. (2012). Diminishing effect of arjuna tree (Terminalia arjuna) bark on the lipid and oxidative stress status of high fat high cholesterol fed rats and development of certain dietary recipes containing the tree bark for human consumption. Research in Pharmacy, 2(4):22-30.

Singh, D.V.; Verma, R.K.; Singh, S.C. and Gupta, M.M. (2002). RP-LC determinationof oleane derivatives in Terminalia arjuna. J. Pharm. Biomed. Anal., 28:447-52.

Singh, N.; Kapur, K.K.; Singh, S.P.; Shanker, K.; Sinha, J.N. and Kohli, R.P. (1982) Mechanism of cardiovascular action of Terminalia arjuna. Planta Med, 45:102-104

Sinha, M.; Manna, P. and Sil, P.C. (2008). Terminalia arjuna protects mouse hearts against sodium fluoride-induced oxidative stress. J. Med. Food, 11:733-740.

Sivakumar, V. and Shanmugam, R. (2014). Screening of cardioprotective effect of Terminalia arjuna Linn. bark in isoproterenol: Induced myocardial infarction in experimental animals. International Journal of Pharma Sciences and Research, 5:262-268.
Sivalokanathan, S.; Vijayababu, M.R. and Balasubramanian, M.P. (2006). Effects of Terminalia arjuna bark extract on apoptosis of human hepatoma cell line HepG2. World J. Gastroenterol, 12:1018-1024.

Soni, N.; Singh, D.; Singh, V. and Singh, V. (2017). Inhibition kinetics of acetylcholinesterase and phosphatases by the active constituents of Terminalia arjuna and Tamarindus indica in the cerebral ganglion of Lymnaea acuminata. Pharmacognosy. Journal, 9:148-156.

Soni, N. and Singh, V. (2019a). Screening of molluscicidal potential of indigenous medicinal plants Terminalia arjuna and Tamarindus indica against fasciolosis vector: Lymnaea acuminate. Asian Journal of Science and technology, 8(8):5256-5261.

Soni, N. and Singh, V. (2015). Molluscicidal activity of Tamarindus indica and Terminalia arjuna against Indoplanorbis exustus: A causative agent of trematodiasis. Sci. Agri., 12(3):163-170.

Soni, N. and Singh, V.K. (2019b). Toxicological safety assessment of molluscicides against non-target aquatic biota; Colisa fasciatus. Int. Ann. Sci., 7:21-27.

Stickel, F. and Schuppan, D. (2007). Herbal medicine in the treatment of liver diseases. Dig. Liver Dis., 39:293-304.

Suman, R.K.; Deshmukh, Y.A.; Maheshwari, U.; Mohanty, I.R. and Borde, M.K. (2018). Natural dipeptidyl peptidase inhibitor Terminalia arjuna mitigates myocardial infarction co existing with diabetes in experimental rats. Journal of Diabetes, Metabolic Disorders and Control, 5(2):48-56.

Sun, F.Y.; Chen, X.P.; Wang, J.H.; Qin, H.L.; Yang, S.R. and Du, G.H. (2008). Arjunic acid, a strong free radical scavenger from Terminalia arjuna. Am. J. Chin. Med., 36:197-207.

Takahashi, S.H.; Tanaka, H.; Hano, Y.; Ito, K.T.; Nomura, T. and Shigenobu, K. (1997). Hypotensive effects in rats of hydrophilic extract from Terminalia arjuna containing tannin related compounds. Phytother. Res., 11: 424-427.a

Tandon, S.; Rastogi, R. and Kapoor, N.K., (1996). Protection by abana, a herbomineral preparation, against Myocardial necrosis in rats induced by isoproterenol. Phytotherapy Research, 10:263-265.

Toppo, E.; SylvesterDarvin, S.; Esakkimuthu, S.; Buvanesvaragurunathan, K.; Ajeesh Krishna, T.P.; Antony Caesar, S.; Stalin, A.; Balakrishna, K.; Pandikumar, P.; Ignacimuthu, S. and Al-Dhabi, N.A. (2018). Curative effect of arjunolic acid from Terminalia arjuna in non-alcoholic fatty liver disease models. Biomed Pharmacother, 107:979-988.

Upadhyay, R.K.; Pandey, M.B.; Jha, R.N., Singh, V.P. and Pandey, V.B. (2001). Triterpene glycoside from Terminalia arjuna. J. Asian Nat. Prod. Res., 3(3):207-212.

Varghese, A.; Savai, J.; Pandita, N. and Gaud, R. (2015). In vitro modulatory effects of Terminalia arjuna, arjunic acid, arjunetin and arjungenin on CYP3A4, CYP2D6 and CYP2C9 enzyme activity in human liver microsomes. Toxicol. Rep., 2:806-816.

Vishwakarma, A.; Vishwe, A.; Sahu, P. and Chaurasiya, A. (2013). Screening of hepatoprotective potential of ethanolic and aqueous extract of Terminalia arjuna bark against paracetamol/CCL4 induced liver damage in Wistar albino rats. International Journal of Pharmaceutical Archive, 2(10):1-7.

Wang, W.; Ali, Z.; Li, X.C.; Shen, Y. and Khan, I.A. (2010). Triterpenoids from two Terminalia species. Planta Med., 76:1751-1754. 